\title{
市中感染の新型コロナウイルス感染症（COVID-19）患者における 咽頭および鼻咽頭拭い液でのウイルス量の推移に関する報告
}

\author{
${ }^{1)}$ 東京慈恵会医科大学感染制御科, ${ }^{2)}$ 東京慈恵会医科大学附属病院感染対策部 \\ 宮島真希子 ${ }^{11}$ 中拂 一彦 ${ }^{1)}$ 保科 斉生 ${ }^{1)}$ 中澤 靖 ${ }^{122}$ \\ 美島 路患 ${ }^{2}$ 澤木 賢司 ${ }^{1)}$ 坂本 洋平 ${ }^{12}$ 李 広烈 ${ }^{1)}$ \\ 保阪由美子 ${ }^{1)}$ 堀野 哲也 ${ }^{1)} \quad$ 吉田 正樹 ${ }^{1)}$ 堀 誠治 ${ }^{1)}$

\section{序文}

新型コロナウイルス感染症（COVID-19）は, 2019 年 12 月に中国武漢市で初めて報告された新型コロナ ウイルス (SARS-CoV-2) による呼吸器感染症である. 流行地域は東アジア, 中東, ヨーロッパ, 北米および 南米へと急速に拡大し, 2020 年 3 月 11 日には WHO よりパンデミック状態であるとの宣言がなされた ${ }^{11}$. 本 邦では, 2020 年 2 月の中旬頃より, 流行地域からの 訪日者や COVID-19 発症者との明らかな接触歴が無 い者, 直近に流行地域の滞在歴が無い者での COVID19 発症の報告が相次いでおり, 2020 年 2 月の段階で 既に散発的に国内で市中感染が生じていた可能性が示 唆されている。 今回我々は，倦点感と食思不振のみを 主訴とする国内市中感染型の COVID-19 発症例を経 験したため, ここに報告する. 本学では, 事前に SARSCoV-2 の検查体制（RT-qPCR（以下 PCR）を用いた 同定・定量）を整備しており，咽頭拭い液と鼻咽頭拭 い液の経時的なウイルス量の変化を確認することがで きたため，この結果も合わせて提示する．本報告を行 うことに関しては，個人情報に十分配慮することを条 件に，患者本人より了承を得ている.

\section{症例}

【患者】 40 代女性. 首都圈 A 県在住.

【生活歴】会社員 (非接客業)。COVID-19 流行地域 への渡航歴, 当該地域出身者との接触歴, あるいは COVID-19 患者（疑い例含む）との明らかな接触歴は なし．自宅でのペット飼育なし，喫煙歴なし．

【病歴】 2020 年 X 月 Y 日（day 0）から倦意感を自

別刷請求先：( ₹ 105-8461）東京都港区西新橋 3 丁目 25-8 東京慈恵会医科大学感染制御科 中拂一彦
覚していた。倦总感は徐々に増し, 次第に食欲も低下 したため，X月 Y +9 日（day 9）に当院内科を受診 した，僚点感出現時から初診時まで発熱はなく，咳嗽 や呼吸困難感などの症状も認めなかった。 バイタルサ インはいずれも正常範囲内であり, 呼吸音, 心音はと もに正常であった。内科初診医の判断により，器質的 疾患の除外目的で胸腹部 CT 検査を施行したところ, 左 S6 に非区域性のスリガラス変化 (Fig. 1A), 左下 葉末梢側に周囲にスリガラス変化を伴う帯状の浸潤影 を認めた (Fig. 1B)。血液検査ではごく軽度の CRP 上昇と白血球減少を認めた（Table 1). インフルエン ザ，マイコプラズマ等の迅速検査は陰性であった，渡 航歴や接触歴などのリスク要因は乏しかったものの, 当時の患者報告状況から COVID-19 の可能性も考え られたため, 同日（day 9）当院感染症科へ入院した.

【入院時現症】意識清明. 体温 $36.6^{\circ} \mathrm{C}$, 脈拍 68 回/ 分, 血圧 $117 / 69 \mathrm{mmHg}, \mathrm{SpO}_{2} 97 \%$ (室内気).

Review of systems (ROS) (+) : 倦㤐感

$\operatorname{ROS}(-)$ : 悪寒 ·頭痛 - 咽頭痛 - 咳嗽 - 鼻汁 ·喀 痰 - 筋肉痛 .下痢

眼瞼結膜貧血なし，眼球結膜黄疸なし，項部硬直な し. 呼吸音, 心音ともに正常. 腹部に異常所見を認め ず.皮疹なし。

\section{【入院後経過】}

入院時点で酸素需要は無く, 状態も安定していた為, 抗菌薬投与は行わずに安静のみで経過をみた。

入院時に採取した咽頭および鼻咽頭拭い液検体を用 いて，施設内で SARS-CoV-2 の PCR を施行したとこ ろ, 入院翌日に両者とも陽性と判明した為, COVID19 と診断した. なお, PCR 検査はドイツの研究グルー 
Fig. 1 Chest computed tomography images at the admission day.

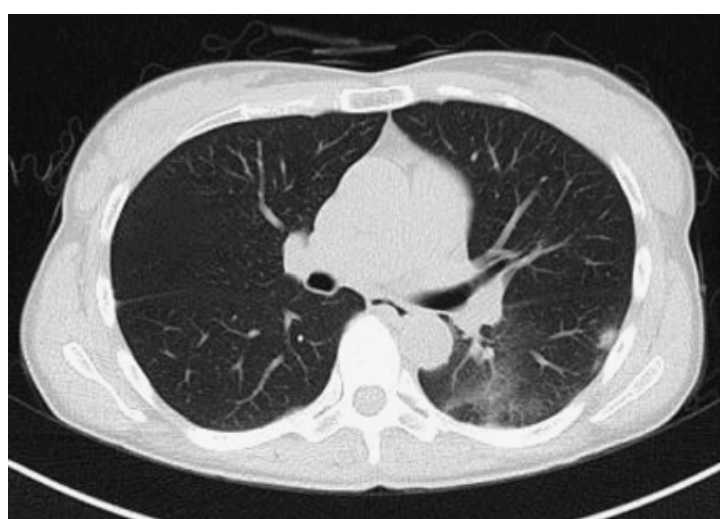

Day 9

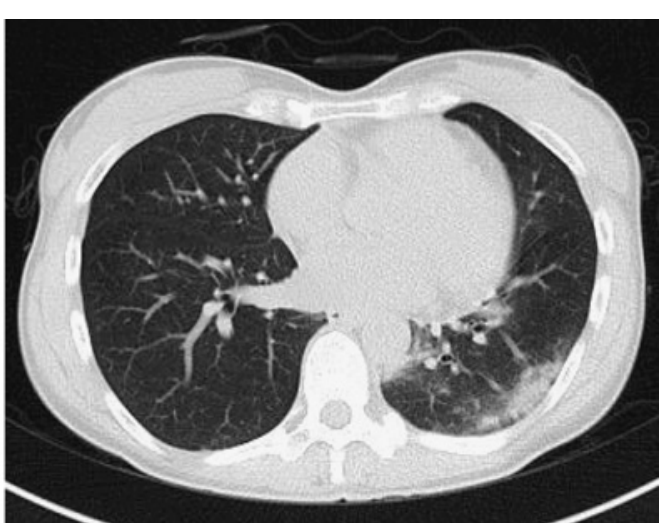

Day 9
Table 1 Laboratory findings at the admission day.

\begin{tabular}{lc|lc}
\hline Hematology & & \multicolumn{2}{|c}{ Biochemistry } \\
WBC & $2,600 / \mu \mathrm{L}$ & $\mathrm{AST}$ & $25 \mathrm{U} / \mathrm{L}$ \\
Neut & $65 \%$ & $\mathrm{ALT}$ & $13 \mathrm{U} / \mathrm{L}$ \\
Lym & $24 \%$ & $\mathrm{LDH}$ & $191 \mathrm{U} / \mathrm{L}$ \\
Mono & $7 \%$ & $\gamma-\mathrm{GTP}$ & $24 \mathrm{U} / \mathrm{L}$ \\
Eosino & $0 \%$ & $\mathrm{TP}$ & $7.4 \mathrm{~g} / \mathrm{dL}$ \\
Baso & $1 \%$ & $\mathrm{Alb}$ & $4.1 \mathrm{~g} / \mathrm{dL}$ \\
Atypical Lym & $2 \%$ & $\mathrm{BUN}$ & $11 \mathrm{mg} / \mathrm{dL}$ \\
$\mathrm{RBC}$ & $4.70 \times 10^{6} / \mu \mathrm{L}$ & $\mathrm{Cr}$ & $0.63 \mathrm{mg} / \mathrm{dL}$ \\
$\mathrm{Hb}$ & $13.1 \mathrm{~g} / \mathrm{dL}$ & $\mathrm{Na}$ & $141 \mathrm{mmol} / \mathrm{L}$ \\
$\mathrm{Ht}$ & $41.0 \%$ & $\mathrm{~K}$ & $4.2 \mathrm{mmol} / \mathrm{L}$ \\
$\mathrm{Plt}$ & $228 \times 10^{3} / \mu \mathrm{L}$ & $\mathrm{Cl}$ & $101 \mathrm{mmol} / \mathrm{L}$ \\
Rapid tests (specimen) & & $\mathrm{CRP}$ & $1.52 \mathrm{mg} / \mathrm{dL}$ \\
Flu (NS) & $(-)$ & & \\
Mycoplasma (TS) & $(-)$ & & \\
Pneumococcus (Urine) & $(-)$ & & \\
Legionella (Urine) & $(-)$ & & \\
\hline
\end{tabular}

NS: Nasal swab TS: Throat swab

プが発表したプロトコルを一部改変して実施した22. プ ライマー・プローブは RdRP gene (RNA 依存性 RNA ポリメラーゼ）領域と, E gene（エンベロープ）領 域を標的としており, 特に RdRP 領域は SARS-CoV-2 に特異的な設計である。咽頭拭い液, 鼻咽頭拭い液は フロックスワブを用いて採取し，検查実施まで $-80^{\circ} \mathrm{C}$ の冷凍庫内に保管した．RNA 抽出はキットのマニュ アルに従った. PCRについては two-step methodを 採用し, 逆転写反応と PCR 反応を別々に実施した. 45 サイクル以内に増幅産物が確認された場合を陽性とし た.

入院 2 日目から徐々に倦点感や食思不振に改善を認 め, 入院 5 日目 (day 13) にはほぼこらは消失した. 入院後呼吸状態の悪化はなく, 胸部単純 X 線画像の 経時的な悪化も認めなかった (Fig. 2). 入院 6 日目 （day 14）に採取した咽頭拭い液で SARS-CoV-2 PCR 陰性を, RdRP gene, E gene 共領域で確認したが, 同
日採取した鼻咽頭拭い液では依然として PCR 陽性で あった。各検査で得られた cycle threshold $(\mathrm{Ct})$ 值 （E gene 領域）の推移を検体別にまとめた（Fig. 3). 最終的に, 入院 15 日目 (day 23) に採取した鼻咽頭 拭い液検体でPCR の陰性を確認し, 数日後当院を退 院した.

な扔本症例では，入院当日（day 9) に採取した検 体の施設内 PCR が陽性と判明した後, 入院 3 日目 （day 11）に採取した咽頭拭い液を用い行政検查を実 施したが，陰性との報告を受けた．本症例の入院時点 では, 当地域における行政検査では鼻咽頭検体は対象 となって㧍らず，この咽頭拭い液での検查結果をもっ て陰性と最終判断された。

\section{考察}

本症例の症状は供总感や食思不振のみであり, 当初 は呼吸器疾患の存在を疑っていなかったが, 器質的疾 患の除外目的で撮影された CT で肺炎像が指摘され, 結果的に COVID-19 の診断に至った. COVID-19 流行 地域の滞在歷, 流行地域住民との接触などがない患者 であり，国内での市中感染が極めて疑われる症例で あった，その後の国内の発生報告や報道, 本人一の詳 細な問診により, 本症例は, 居住地近辺のレクリエー ション施設内でクラスター感染を起こした可能性が極 めて高いことが判明した。

本症例では, 入院中に複数回の検体採取と PCR を 行うことで, 発症後のウイルス量の推移を検体別に確 認することができた。入院日（day 9）に採取した検 体での PCR の結果から, 鼻咽頭拭い液のウイルス量 は咽頭拭い液と比べ 2,000 倍程度 (211 倍) 多いことが 示された。また鼻咽頭拭い液検体では，咽頭拭い液に 比べ 10 日間程度陽性を示す期間が長く, 部位により ウイルスを排出している期間が異なる可能性が示唆さ れた。同様の結果は, 中国・広東省疾病管理予防セン ターのZou らによる, 確定症例（17 例）に抒けるウ 
Fig. 2 Chest X-ray images during hospitalization.

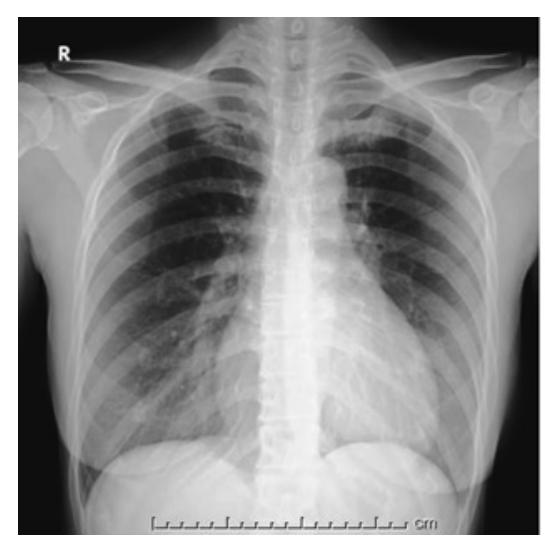

Day 10

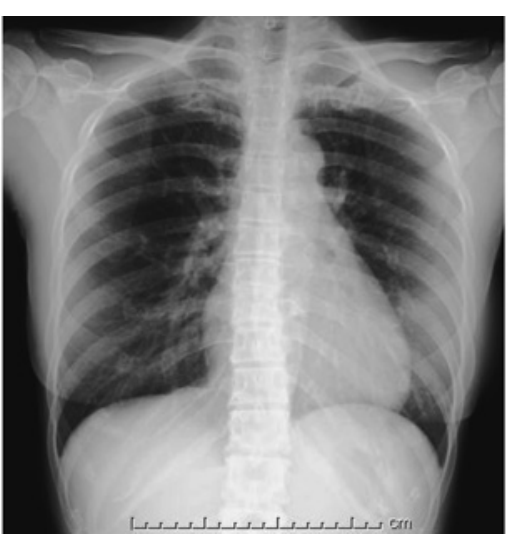

Day 12

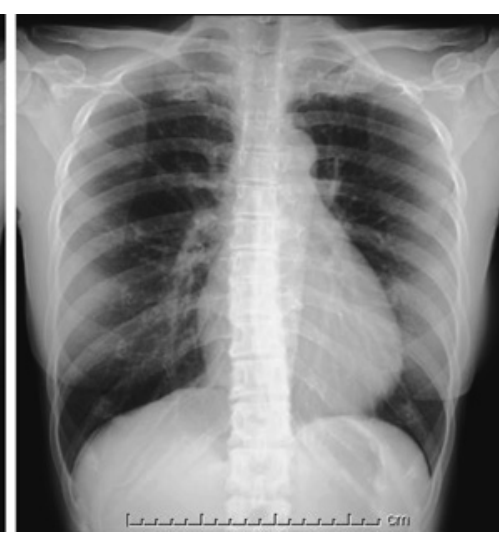

Day 15

Fig. 3 Viral load detected in nasal and throat swabs.

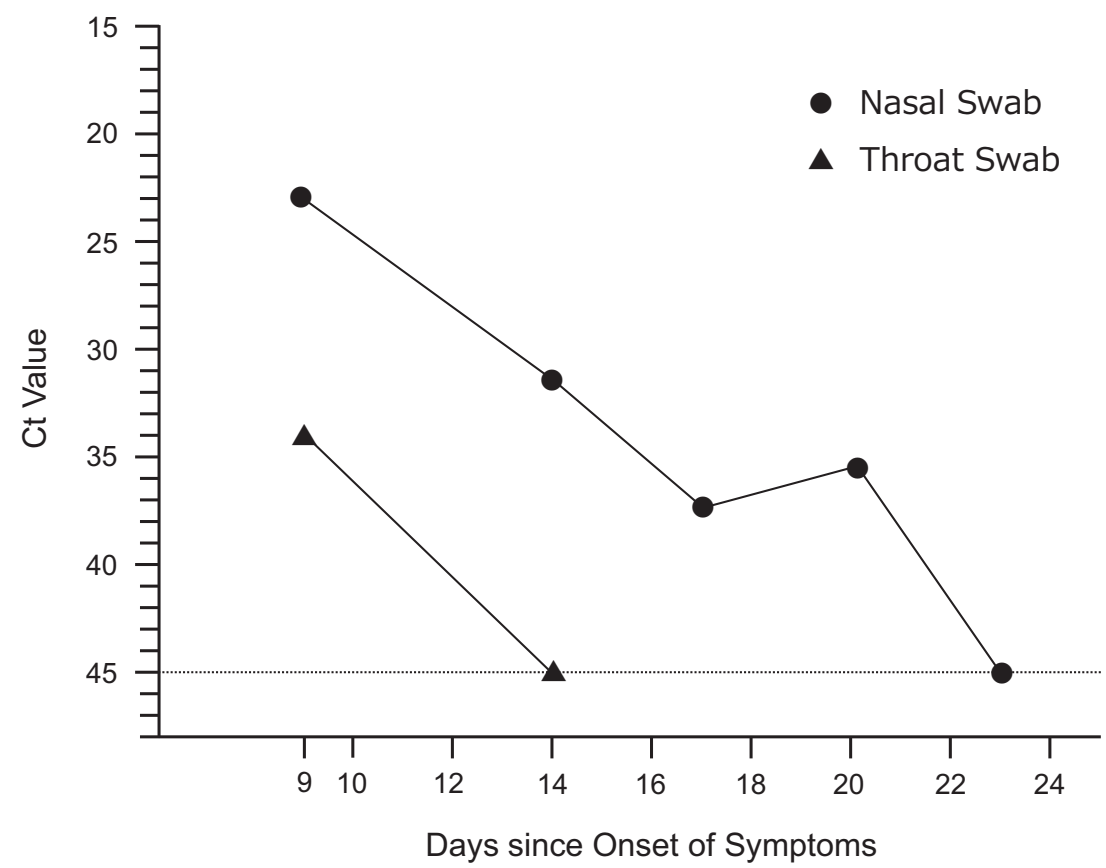

イルス量の推移に関する報告でも示されている ${ }^{3)}$ PCR を診断で用いる場合, 陽性例を確実に拾い上げるとい う意味では，咽頭拭い液よりも鼻咽頭拭い液のほうが 検査に適している可能性がある。但し，PCR が陽性 であることは感染性をもったウイルスを排出している ことと同義では無いため, 退院基準としてどこまで PCR を用いるべきかには議論の余地がある，本症例 のように症状が完全に消失したあとも長期に検査陽性 となるケースもあり, この場合, 軽症者による入院ベッ ドの長期占有や検査に関わる人的・物的リソースの逼 迫，また患者本人の心身両面での負担増加なども大き な問題となる。今後さらに知見が積み重ねられ，患者 や周囲の人間の安全が担保される条件が見出されれ
ば，症状消失から一定期間経過した段階での退院を許 容しその後は必要に応じて自宅安静期間を設けるな ど, より柔軟な対応も検討されるべきだと考える.

咽頭拭い液を対象とした施設内検査と行政検査で異 なる結果が出た要因として, 検体採取の夕イミングの 違い（本症例の場合 2 日間の差）以外には，実施した PCR 検査の感度の違いが考えられる. 感度の違いが 生まれる主たる要因として, RNA から cDNA を合成 する（逆転写反応）際のプロトコルの違い, 標的とす る遺伝子領域の違いが考えられる。例えば，逆転写反 応に one-step methodを採用した場合, cDNA 量の十 分な確保が達せられていない可能性がある。 また, 国 立感染症研究所の「新型コロナウイルス感染症 病原 
体検出マニュアル」では当初 N gene（ヌクレオカプ シド）の 2 領域を標的としていたが, RdRP geneや E gene 領域を標的とした PCR と感度を比較した報告 はない. いずれのプロトコルも SARS-CoV-2 を特異 的に検出可能な検査方法であり，検査が陽性であれば 感染の可能性は高いが, 陰性の場合に感染を否定する ことは難しい. 本症例で見られた検査結果の解離は, PCR に基づいた診断の限界を表しているとも考えら れる，前述したように，検査を実施するタイミングや 検査検体の選択によっても結果が左右される可能性が あることを踏まえると, 症状や経過から COVID-19 が疑われる症例では, PCR が陰性であっても咳エチ ケットや手指衛生の遵守, 不要不急の外出を控え自宅 療養すること等を指導し, 感染拡大の防止に努めるこ とが重要であると考えられた。

謝辞：未知な疾患に対する不安の中で懸命に患者の ケアにあたっていただいている当院スタッフの皆様, また夜間休日を問わず検査や相談に応じていただいた 行政の皆様のご尽力に，心から御礼を申し上げます.
また自施設内での PCR 検査体制の構築と運用にあた り, 東京慈恵会医科大学熱帯医学講座の嘉糠洋陸先生, 大手 学先生, 櫻井達也先生, 齊木選射先生, 東京慈 恵会医科大学臨床検査医学講座の松浦知和先生と政木 隆博先生にご協力いただきました。 ここに厚く御礼申 し上げます。

利益相反自己申告 : 申告すべきものなし

$$
\text { 文献 }
$$

1) World Health Organization : WHO characterizes COVID-19 as a pandemic [Internet]. [cited 2020 Mar. 11]; Available from: https://www.w ho.int/emergencies/diseases/novel-coronavirus2019/events-as-they-happen.

2) Corman VM, Landt O, Kaiser M, Molenkamp R, Meijer A, Chu DK, et al. : Detection of 2019 novel coronavirus (2019-nCoV) by real-time RTPCR. Euro Surveill. 2020 ; 25 (3) : 2000045.

3) Zou L, Ruan F, Huang M, Liang L, Huang H, Hong Z, et al. : SARS-CoV-2 Viral Load in Upper Respiratory Specimens of Infected Patients. N Engl J Med. 2020 ; 382 (12) : 1177-9.

A Report on Changes in The Viral Load in Pharyngeal and Nasopharyngeal Swab Specimens in A Patient with Community-acquired Coronavirus Infection 2019 (COVID-19)

Makiko MIYAJIMA $^{1)}$, Kazuhiko NAKAHARAI ${ }^{1)}$, Tokio HOSHINA ${ }^{1)}$, Yasushi NAKAZAWA ${ }^{12)}$, Yukie MISHIMA ${ }^{2)}$, Kenji SAWAKI'), Yohei SAKAMOTO' ${ }^{1)}$ Kwangyeol LEE ${ }^{1)}$, Yumiko HOSAKA ${ }^{1)}$, Tetsuya HORINO ${ }^{1)}$, Masaki YOSHIDA ${ }^{1)} \&$ Seiji HORI ${ }^{1)}$

${ }^{1}$ Department of Infectious Diseases and Infection Control, Jikei University School of Medicine, ${ }^{2}$ Department of Infection Control, Jikei University Hospital

Coronavirus infection 2019 (COVID-19) is a respiratory infection caused by a novel coronavirus (SARSCoV-2) that was first reported in Wuhan, China, in December 2019. In Japan, since mid-February 2020, there have been a series of reports of COVID-19 outbreaks among people without apparent contact with COVID19 patients or visitors to Japan from endemic areas, or a recent history of visiting an endemic area. We encountered a patient with COVID-19 arising from local community transmission of infection, who presented with the chief complaints of fatigue and anorexia. In this patient, a quantitative polymerase chain reaction (PCR) assay showed a higher viral load and a more extended period of viral excretion in nasopharyngeal swab specimens than in pharyngeal swab specimens. When using a PCR assay as a diagnostic test or as an indicator of improvement, we should be aware of the characteristics and limitations of the test.

〔J.J.A. Inf. D. 94 : 587 590, 2020] 